\title{
Impact of Coronavirus and Macroeconomic Indicators on Sharia Obligation with Simultaneous Model
}

\author{
Anton Bawono ${ }^{1 *}$, Mohammad Rofiuddin ${ }^{2}$, Rifda Nabila ${ }^{3}$, Saiful Anwar ${ }^{4}$ \\ 1, 2, 3, 4 IAIN Salatiga, Indonesia \\ E-mail: ${ }^{1}$ alfathbawono@gmail.com, ${ }^{2}$ mohammad.rofiuddin@iainsalatiga.ac.id, \\ ${ }^{3}$ rifdanabila@iainsalatiga.ac.id, ${ }^{4}$ saifulanwarmieta@iainsalatiga.ac.id \\ *) Corresponding author
}

JEL Classification:

$\mathrm{C} 30$

G12

$\mathrm{O} 10$

Received: April 15, 2021

Revised: May 25, 2021

Accepted: June 28, 2021

\begin{abstract}
This study examines the macroeconomic variables exchange rate and $B I$ rate in collaboration with the Coronavirus Disease case against Sukuk. In addition, this study also examines the exchange rate influenced by the $B I$ rate variable and the case of Coronavirus Disease. The data analysis method in this study uses a simultaneous equation model Two-Stage Least Square. This study found that the exchange rate affects the demand for Sukuk while the BI rate does not affect it. But what is surprising is that when the Coronavirus Disease 2019 case occurred, it did not affect the demand for Sukuk. This study also found that the exchange rate is influenced by the $B I$ rate and the case of Coronavirus Disease. The contribution of this research is that when the government cannot intervene in the exchange rate, which can affect the demand for Sukuk, it can be done by intervening in the BI rate.
\end{abstract}

\section{Keywords:}

Sukuk, Exchange rate, BI rate, Coronavirus Disease.

\section{How to Cite:}

Bawono, A., Rofiuddin, M., Nabila, R., \& Anwar, S. (2021). Impact of Coronavirus and Macroeconomic Indicators on Sharia Obligation with Simultaneous Model. Signifikan: Jurnal Ilmu Ekonomi, 10(2), 291-298. https://doi.org/10.15408/sjie.v10i2.21084. 


\section{Introduction}

Sukuk is currently a sharia financial instrument capable of moving the wheels of the country's economy and represents the second-largest Islamic financial industry after Islamic banking. The growth of Sukuk is increasingly significant, which is strengthened by the presence of eight non-Islamic member countries of the OIC who are interested in issuing Sukuk on the global market (Smaoui \& Ghouma, 2020). Moreover, Sukuk can contribute $90 \%$ of alternative funding (Al-Sayed, 2013) for corporations and the state. Sukuk has become an attractive instrument for Muslim and non-Muslim investors. Muslim and nonMuslim investors interested in investing in Sukuk securities, of course, consider these factors.

The essential factor in maintaining the investment climate is the stability of macroeconomic variables, including investment in Sukuk. Several researchers have researched the factors that influence the development of the Sukuk market, as done by Smaoui \& Khawaja (2017) and Smaoui et al. (2017). Khalifah et al. (2017) found that the exchange rate has an effect on sukuk. However, Yung (2021) found that interest rates also caused exchange rate fluctuations. Liu \& Lee (2020) explain the effect of interest rate adjustment on exchange rate volatility in China/the US. Furthermore, changes in the exchange rate of China/US have a slightly more substantial effect on interest rates in the US than on interest rates in China. Fluctuations in interest rates can also create economic uncertainty that has an impact on investor confidence. Investors will not hold the sukuk securities they hold in the future. $\mathrm{Mu}$ (2013) explained that the sukuk will be influenced by interest rates such as bonds. In bond securities, Bhattacharyay (2013) found that the volatility of interest rest will reduce investors' purchasing power of sukuk. However, it is also different from the findings Ependi \& Thamrin (2020) which found that the interest rate has no effect on the development of the sukuk market.

This study tries to provide new insight into the correlation between the exchange rate and the BI rate on Sukuk when there is a PSBB in Indonesia. Coronavirus Disease is designated as a national non-natural disaster caused by a deadly disease outbreak. Pandemics are one of the primary sources of risk in financial markets. Sharif et al. (2020) found that pandemics impact geopolitics and the economy, giving rise to policy uncertainty. Researchers found that the Covid-19 pandemic had multiple financial effects (Akhtaruzzaman et al., 2021; Corbet et al., 2020; Rahmadia \& Febriyani, 2020; Selasi, 2010; Sharif et al., 2020), including Sukuk. Even though the Islamic financial market is safer than conventional during the global financial crisis (Aloui et al., 2018), gold and cryptocurrency have become safe investments at the beginning of the Covid-19 pandemic (Corbet et al., 2020). This means that the development of the Sukuk market can decrease by covid because investors prefer gold and cryptocurrency. Rahmadia \& Febriyani (2020), in their research, found that movements in the exchange rate and oil prices that occur continuously require the government to take an interest rate adjustment policy immediately. Covid-19 first entered Indonesia on March 2, 2020, and forced the government to impose Large-Scale Social Restrictions (PSBB). Every time there is an increase in positive cases of Covid-19 in Indonesia, the exchange rate against the US Dollar will weaken. 
The inconsistency of research findings on macroeconomic variables proxied by the exchange rate and BI rate on Sukuk is very important to investigate. The novelty of this study builds insight into the simultaneous model between macroeconomic variables and the 2019 Coronavirus Disease on Sukuk. For this reason, this study aims to examine the macroeconomic variables of the exchange rate and BI rate in collaboration with the 2019 Coronavirus Disease case against Sukuk. In addition, this study also tested the exchange rate influenced by the BI rate variable and the 2019 Coronavirus Disease case and tested the BI rate influenced by the 2019 Coronavirus Disease case.

\section{Methods}

Data in this study are secondary data. The data used includes data on Sukuk, exchange rates, interest rates, Covid cases sourced from Bank Indonesia, Covid Center, trading economics, Indonesian Stock Price Appraisers. Variables used in this study are (1) Sukuk are fixed income instruments issued based on sharia principles by OJK regulations concerning Sharia Securities. The Sukuk data used in this research is proxied by using the Indonesian Sukuk Index Composite (ISIXC) data with a unit price, (2) Exchange rate is the price of one unit of foreign currency in domestic currency. In other words, the price of a currency is exchanged for another currency. The exchange rate that is often used is the rupiah exchange rate against the dollar. The exchange rate data used in this study is the purchase rate in rupiah units, (3) Interest rate is the interest rate expressed in percent for a specific time (monthly or annually). Interest rates in the study use Indo, which reflects interest rates that occur on the money market, which is calculated periodically, is available and can be used by market players as references such as setting loan interest rates, pricing financial instruments, and measuring financial instrument performance. The Indo unit is percent, (4) Covid-19 cases are the number of positive people or those caused by the severe acute respiratory syndrome coronavirus 2 (SARS-CoV-2).

This study uses a simultaneous equation model. The simultaneous equation model consists of more than one dependent variable and more than one related equation (Gujarati, 2004). In short, a variable has two roles at once, namely as an independent variable and as an independent variable called an endogenous variable and an exogenous variable as an independent variable in the simultaneous equation model. The simultaneous equation model in this study uses the Two-Stage Least Square method approach. The Two-Stage Least Square (2SLS) method is one of the regression methods included in the structural equation analysis group. The 2SLS method is used when there is a correlation between the independent variables and the error. The structural equation form of the simultaneous equation model is as follows (Gujarati, 2004).

Sukuk $=\beta_{0}+\beta_{1}$ Exchange $+\beta_{2}$ Indo $+\beta_{3}$ Covid + et

Exchange $=\beta_{0}+\beta_{1}$ Indo $+\beta_{2}$ Covid + et

Indo $=\beta_{0}+\beta_{1}$ Covid + et 
Note:

Sukuk : Indonesian Sukuk Index Composite (ISIXC)

Exchange : Exchange rate value

Indo : Interest rate

Covid : Number of covid case

These three equations can be seen in the relationship between variables shows in Figure 1.

Figure 1. The Research Framework

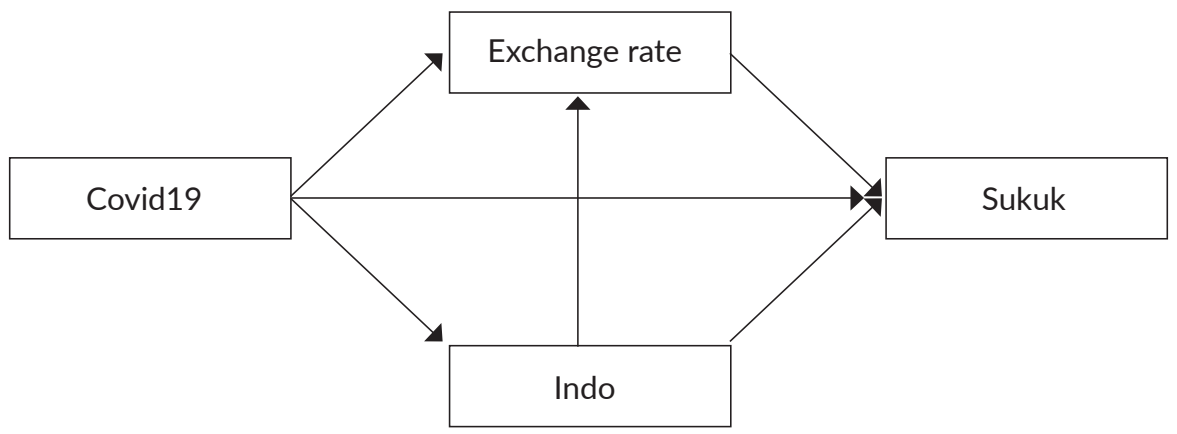

\section{Result and Discussion}

Descriptive statistical analysis is a statistic that describes or provides an overview of the object under study through sample or population data as it is and makes general conclusions. The results of descriptive statistical analysis are shown in Table 1.

Table 1. Descriptive Statistical Analysis Results

\begin{tabular}{ccccc}
\hline & ISIXC & Exchange Rate & Indo & KASUS_C \\
\hline Mean & 253.1537 & 15151.94 & 4.375191 & 9494.985 \\
Median & 251.9612 & 15007.59 & 4.319620 & 5923.000 \\
Maximum & 260.7769 & 16657.30 & 4.612990 & 34316.00 \\
Minimum & 246.1308 & 13886.22 & 4.295870 & 2.000000 \\
Std. Dev. & 3.986024 & 790.9365 & 0.110061 & 10213.24 \\
\hline
\end{tabular}

Source: Data processed (2021)

This study uses a Two-Stage Least Square approach. This model is used to determine the effect of the independent variable on the dependent variable. The estimation results of each equation are as follows. Estimation Results of the Common Effect Model Approach. In Table 2, the simultaneous equation model with Two-Stage Least Square is as follows:

Sukuk $=-0.11471-0.0044$ Exchange -2.36129 Indo +0.00014 Covid -0.164365 MA(1) (1)

Exchange rate $=40.20055-1438.147$ Indo -0.096539 Covid

Indo $=0.006472-2.04 \mathrm{E}-05$ Covid

The t-test is used to determine whether changes in each independent variable can explain changes in the dependent variable. This method is carried out on the regression 
equation obtained from the relationship of each independent variable individually (partially) to the dependent variable by comparing the coefficient values in the significant column according to each of the independent variables. The t-test results are as in Table 3.

Table 2. Estimation Results of the Common Effect Model Approach

\begin{tabular}{cccc}
\hline Variable & Sukuk & Exchange Rate & Indo \\
\hline C & -0.11471 & 40.20055 & 0.006472 \\
D(Exchange Rate) & $-0.0044^{* *}$ & $-1438.147^{*}$ & $-2.04 \mathrm{E}-05^{*}$ \\
D(INDO) & -2.36129 & $-0.096539^{*}$ & \\
D(KASUS_C) & 0.00014 & & \\
MA(1) & -0.164365 & & \\
\hline R-squared & 0.183576 & 0.208451 & 0.086665 \\
Adjusted R-squared & 0.126283 & 0.182498 & 0.071933 \\
\hline
\end{tabular}

Note: ${ }^{*}$ significant at 0,$01 ;{ }^{* *}$ significant 0,$05 ;{ }^{* * *}$ significant at 0,1

Based on Table 3, the effect of each variable can be explained as follows. First, There is an effect of the exchange rate on the Sukuk. The more the exchange rate increases, the Sukuk value decreases, and vice versa. Second, there is no effect of interest rates on Sukuk. The more the interest rate increases; the Sukuk value does not increase or decrease. Third, there is no effect of the covid case on Sukuk. The more the covid case value increases; it does not cause an increase or decrease in the value of the Sukuk. Fourth, there is an effect of interest rates on the exchange rate. The higher the interest rate, the lower the exchange rate, and vice versa. Fifth, there is an effect of the covid case on the exchange rate. The more the Covid case value increases, the exchange rate decreases, and vice versa. Sixth, there is an effect of the covid case on interest rates. The more the Covid case value increases, the lower the interest rate will be, and vice versa.

Table 3. t-test result

\begin{tabular}{cccccc}
\hline Dependent & Independent & Coefficient & Std. Error & t-Statistic & Probability \\
\hline Sukuk & Exchange Rate & -0.004441 & 0.001692 & -2.624690 & 0.0111 \\
Sukuk & INDONIA & -2.361290 & 4.376451 & -0.539545 & 0.5916 \\
Sukuk & KASUS_C & 0.000140 & 0.000265 & 0.530144 & 0.5981 \\
Exchange Rate & INDONIA & -1438.147 & 439.0513 & -3.275579 & 0.0017 \\
Exchange Rate & KASUS_C & -0.096539 & 0.030438 & -3.171624 & 0.0024 \\
Indo & KASUS_C & $-2.04 \mathrm{E}-05$ & $8.41 \mathrm{E}-06$ & -2.425502 & 0.0182 \\
\hline
\end{tabular}

The results showed that the exchange rate harmed the value of the Sukuk. An increase exchange rate impacts change the value of the Sukuk in the market so that the existence of the exchange rate needs to be maintained stably. Empirically the results of this study are in line with research conducted by (Ardiansyah \& Lubis, 2017), which found that exchange rates negatively affect the growth of corporate Sukuk in Indonesia. This alignment makes it clear that the strengthening of the exchange rate during the Covid-19 pandemic 
will directly have a good impact on the value of the Sukuk. This condition occurs because Sukuk provides more promising returns for investors in placing their business portfolios. Aside from that, it's impossible to ignore Sukuk's track record, which has been steadily improving year after year. Because however, in terms of business, it cannot be separated from fundamental economic analysis, which means that the exchange rate provides a good signal for investors to invest or shift their business portfolio to Sukuk. These results are also in line with research conducted by Smaoui and Khawaja (2017), Smaoui et al. (2017), and Khalifah (2017) find that there is an effect of the exchange rate on Sukuk. Simply put, the strengthening of the rupiah during the Covid-19 pandemic will encourage the public/ investors to choose the right investment place, and value adds value, in this case, Sukuk.

Exchange rates that affect Sukuk, in other conditions, the results of the study show that interest rates influence the exchange rate. This means that the ups and downs of interest rates during the Covid-19 pandemic can affect the exchange rate fluctuation. Empirically, the results of this study are in line with research conducted by Arifin (2003), which shows that interest rates are very effective in strengthening exchange rates. Likewise, with the research of Yung (2021) and Liu and Lee (2020) found that there is an effect of interest rates on the exchange rate. This condition clarifies a need for a measured policy in maintaining the exchange rate during the Covid-19 pandemic because determining the correct interest rate will encourage the strengthening of the exchange rate. In contrast, an inaccurate interest rate will lead to the wrong direction for the economy. This determination is by Rahmadia and Febriyani (2020) opinion that the continuous exchange rate movements require the government to adopt an interest rate adjustment policy immediately. Furthermore, there needs to be a policy related to measurable interest rates in simple terms because a measured interest rate will also have a measurable impact on strengthening the exchange rate.

The results of this study are not in line with research conducted by Akçağlayan (2008), which found that an increase in interest rates causes depreciation in the domestic currency. Thus, it is necessary to be vigilant in determining interest rates, especially during a relatively very sensitive pandemic in all conditions. Another condition that causes interest rates to strengthen the exchange rate is that a higher interest rate will increase the interest of a person or society to put their money in sacrifice or domestically. Therefore, it will be pretty effective in anticipating the flight of money abroad.

The development of the Covid-19 case in this result shows a negative influence on the exchange rate. This means that every increase in cases of Covid19 will impact the strengthening of the exchange rate. This condition cannot be separated due to global conditions because at the beginning of Covid, Indonesia only found cases of Covid on March 2, 2019, or three months after the first case was found, while other countries have found many cases. This means that the existence of the Covid19 case has an impact on the exchange rate. However, it is necessary to be aware of the impact because market conditions are relatively much affected by fundamental economic issues, which can fluctuate at any time.

This result is empirically not in line with Haryanto (2020) research, which states that the Covid-19 case impacts exchange-rate depreciation. This condition certainly cannot be separated because there is no economic certainty during the pandemic, impacting the 
flow of incoming funds. However, the opposite can happen; the flow of funds tends to come out because of this uncertainty. Given these circumstances, there must be policies that can reduce investor fear in making investments. This will have a positive impact on the economy. But, on the other hand, if the anticipation of economic uncertainty is not carried out properly, it will impact the loss of interest of investors to invest their capital. So, the policies taken to control Covid-19 do not have a proper impact on the domestic exchange rate. The covid case on interest rates has a negative effect. This means that an increase in the case of Covid-19 will have an impact on lowering interest rates. This condition cannot be separated because the Covid-19 case provides economic uncertainty, which in the end also has an impact on policy uncertainty. This is consistent with Sharif et al. (2020), who found that pandemics have geopolitical and economic impacts. Normatively it can be interpreted that an increase in covid cases will have an impact on interest rate changes, so there is a need for efforts to suppress the covid cases to decrease.

These results can also explain that COVID-19 has forced banks to carry out strategic policies, including interest rate policies. This condition cannot be separated from the context of maintaining banking in good funding and fundraising conditions. Thus, there needs to be a response or policy specifically related to banking so that the Covid-19 does not have an outsized impact on banking. In addition, the decline in interest rates is also difficult for customers to respond to because customers themselves experience the same condition, namely fear of economic uncertainty caused by COVID-19.

\section{Conclusion}

Based on results and discussion, it can be concluded that what directly influences Sukuk is the exchange rate, while interest rates and the case of covid-19 do not affect Sukuk. However, interest rates and the case of covid-19 have an indirect effect on Sukuk through the exchange rate. On the other hand, interest rates are also affected by an increase in covid cases.

This research implies that the government can strengthen the policy mix to increase investors' interest in Sukuk to ensure economic stability and encourage economic recovery during the COVID-19 pandemic. The policy can be in the form of government intervention and Bank Indonesia against the BI rate to attract investors to participate in the purchase of Sukuk.

\section{References}

Akçağlayan, A. (2008). The Effects of Interest Rate Policy on Exchange Rates During 2001 Currency Crises. Abant Izzet Baysal University Journal of Social Sciences, 9(1), 1-20.

Akhtaruzzaman, M., Boubaker, S., \& Sensoy, A. (2021). Financial Contagion During COVID-19 Crisis. Finance Research Letters, 38, 1-36.

Al-Sayed, O. (2013). Sukuk Risk: Analysis and Management. European Journal of Applied Social Sciences Research, 1(3), 67-76.

Aloui, C., Jammazi, R., \& Hamida, H. B. (2018). Multivariate co-movement between Islamic 
Stock and Bond Markets among the GCC: a Wavelet-based View. Computational Economics, 52(2), 603-626. https://doi.org/10.1007/s10614-017-9703-7

Ardiansyah, I. H., \& Lubis, D. (2017). Pengaruh Variabel Makroekonomi terhadap Pertumbuhan Sukuk Korporasi di Indonesia The Effect of Macroeconomic Variables to Corporate Sukuk Growth in Indonesia 1 Pendahuluan. Al-Muzara'ah, 5(1), 51-68.

Arifin, S. (2003). Efektifitas Kebijakan Suku Bunga Dalam Rangka Stabilisasi Rupiah Di Masa Krisis. Buletin Ekonomi Moneter Dan Perbankan, 1(3), 1-26.

Bhattacharyay, B. N. (2013). Determinants of bond market development in Asia. Journal of Asian Economics, 24, 124-137.

Corbet, S., Larkin, C., \& Lucey, B. (2020). The Contagion Effects of the COVID-19 Pandemic: Evidence from Gold and Cryptocurrencies. Finance Research Letters, 35, 1-7.

Ependi, H., \& Thamrin, H. (2020). The Effect of Macroeconomic Factors on The Number of Corporate Sukuk Offers in Indonesia. Dinasti International Journal of Economics, Finance \& Accounting, 1(4), 593-605. https://doi.org/10.38035/dijefa.v1i4.532

Gujarati, D. N. (2004). Basic Econometrics (Fourth edi). New Yok: McGraw-Hill Inc.

Khalifah, M. H., Soleh Nurzaman, M., \& Cholil Nafis, M. (2017). Optimization of BAZNAS Programs on Sustainable Development Goals (SDGs): Analytic Network Process Approach (ANP). International Journal of Zakat, 2(2), 71-83.

Haryanto, H. (2020). Dampak Covid-19 terhadap Pergerakan Nilai Tukar Rupiah dan Indeks Harga Saham Gabungan (IHSG). Jurnal Perencanaan Pembangunan: The Indonesian Journal of Development Planning, 4(2), 151-165.

Liu, T., \& Lee, C. (2020). Exchange Rate Fluctuations and Interest Rate Policy. International Journal of Finance \& Economics, 1-19. https://doi.org/10.1002/ijfe.2336

Mu, Y., Phelps, P., \& Stotsky, J. G. (2013). Bond markets in Africa. Review of Development Finance, 3(3), 121-135. https://doi.org/10.1016/j.rdf.2013.07.001

Rahmadia, S., \& Febriyani, N. (2020). Dampak Covid-19 terhadap Ekonomi. Jurnal Ekonomi Islam(JE Islam), 1(1), 1-9.

Selasi, D. (2010). Dampak Pandemic Disease Terhadap Perkembangan Pasar Modal Syariah di Indonesia. Syintax Literate: Jurnal Ilmiah Indonesia, 5(5), 46-54.

Sharif, A., Aloui, C., \& Yarovaya, L. (2020). COVID-19 Pandemic, Oil Prices, Stock Market, Geopolitical Risk and Policy Uncertainty Nexus in the US economy: Fresh Evidence from the Wavelet-based Approach. International Review of Financial Analysis, 70, 1-9. https://doi.org/10.1016/j.irfa.2020.101496

Smaoui, H., \& Ghouma, H. (2020). Sukuk Market Development and Islamic Banks' Capital Ratios. Research in International Business and Finance, 51, 1-17.

Smaoui, H., \& Khawaja, M. (2017). The Determinants of Sukuk Market Development. Emerging Markets Finance and Trade, 53(7), 1501-1518.

Smaoui, H., Mimouni, K., \& Temimi, A. (2017). Sukuk, Banking System, and Financial Markets: Rivals or Complements?. Economics Letters, 161, 62-65.

Yung, J. (2021). Can Interest Rate Factors Explain Exchange Rate Fluctuations?. Journal of Empirical Finance, 61, 34-56. https://doi.org/10.1016/j.jempfin.2021.01.005 